\title{
The decline of jaguars Panthera onca in the Argentine Chaco
}

\author{
Mariana Altrichter, Gabriel Boaglio and Pablo Perovic
}

\begin{abstract}
We assessed the distribution and status of jaguar Panthera onca in the Argentine Chaco, one of the least known areas within its range. Current jaguar distribution in the Chaco encompasses parts of central and western Formosa, western Chaco, eastern Salta and north-eastern Santiago del Estero Provinces. Jaguar range was reduced following colonization of the semiarid Chaco even though there has been little deforestation. Jaguars have not been observed over the last 15 years in areas where colonization occurred more than 35 years ago, probably reflecting hunting pressure. Livestock predation is lower now than when the area was first settled in the 1920s. This may indicate low jaguar
\end{abstract}

densities as the livestock management system has not changed. Local people, however, continue to hunt jaguars with the intention of exterminating them. Education, enforcing jaguar hunting laws, increasing control of poaching in protected areas, and creating more protected areas may be the most efficient strategies to preserve the jaguar population of the Argentine Chaco.

Keywords Argentina, Chaco, jaguar, Panthera onca, poaching, predation.

This paper contains supplementary material that can only be found online at http://journals.cambridge.org

\section{Introduction}

Conflicts between humans and wildlife are more acute when coexistence produces negative consequences for humans, and such is the case with large felids such as jaguars Panthera onca preying upon domestic animals and threatening human life. This conflict occurs throughout the distribution range of jaguars, resulting in their persecution (Hoogesteijn et al., 1993; Jorgenson \& Redford, 1993; Nowell \& Jackson, 1996). The jaguar now survives in only a fraction of its former range (Swank \& Teer, 1989; Rabinowitz, 1995) and is categorized as Near Threatened on the IUCN Red List (IUCN, 2006).

In Argentina this species was once distributed from the north of the country south to Patagonia (Guggisberg, 1975 ) but its range has been reduced by c. $85 \%$ (Perovic, 2002a). The ecology and conservation status of jaguar has been studied in the north-east tropical forest of Misiones (Schiaffino et al., 2002) and in the north-west tropical Yungas (Perovic \& Herran, 1998; Perovic, 2002a), but not

Mariana Altrichter* (Corresponding author) School of Natural Resources, University of Arizona, 104 BioScience, Tucson, AZ 85721, USA.

E-mail marianaalt@msn.com

Gabriel Boaglio Facultad de Ciencias Naturales, Universidad Nacional de Córdoba, Argentina.

Pablo Perovic Instituto de Bio y Geociencias, Museo de Ciencias Naturales, Universidad Nacional de Salta, Argentina.

${ }^{*}$ Current address: Center for Environmental Studies, University of Redlands, 1200 East Colton Avenue, P.O. Box 3080, Redlands, CA 92373-0999, USA.

Received 14 December 2004. Revision requested 18 March 2005. Accepted 18 October 2005 in the Chaco region (Perovic, 2002a), for which contradictory information has been presented by different authors. Arra (1974) described jaguar distribution across the Chaco and the Yungas as if they are one connected area, separated from the Paranaense forest of Misiones. Olrog \& Lucero (1981) defined the same distribution as three separated areas. Roig (1991) described the entire northeast to north-west region of the country as the jaguar's distribution, whereas Swank \& Teer (1989) and Redford \& Eisenberg (1992) did not include the Chaco in the jaguar's distribution. Data from the Bolivian Chaco (Maffei et al., 2004) suggest that jaguars are widespread in forest types similar to those found in the Argentine Chaco. Because of this inconsistent information the Argentine Chaco has been highlighted as one of the priority sites for which research on jaguars is required (Sanderson et al., 2002). Responding to this need, we assessed the status and distribution of jaguars in this area.

The main causes of jaguar population declines throughout its range are habitat loss and hunting as a result of conflicts with livestock (Swank \& Teer, 1989; Rabinowitz, 1995). It is important to assess these factors independently, however, because the presence of good habitat may not always guarantee a species' persistence if hunting is causing population declines. The semi-arid Argentine Chaco has been degraded by overgrazing and selective logging, but not by large-scale deforestation (Bucher \& Huszar, 1999). For this reason, reduction of jaguar range in this area could be attributed more to hunting than to habitat destruction. To test this hypothesis, we collected information about presence of jaguars and time of human colonization. 
Whether hunting causes local extirpation of jaguars can also be assessed, in part, by understanding how local people perceive and react to the presence of this species. In the Pantanal of Brazil, for example, attitudes towards jaguars are mixed and difficult to predict on the basis of socio-economic factors (Zimmerman et al., 2005). For carnivores that conflict with humans the conservation challenge lies in understanding human behaviour and attitudes towards predators because humans ultimately determine the course and resolution of conflicts (Sillero \& Laurenson, 2001; Manfredo \& Dayer, 2004). Local people generally hold negative attitudes towards large carnivores that prey upon livestock (Kellert, 1996; Kellert et al., 1996). For these reasons, we assessed local people's perceptions and reactions towards jaguar presence.

\section{Study area}

Our survey covered an area of c. $240,000 \mathrm{~km}^{2}$ of the northern Argentine Chaco, covering parts of Salta, Formosa, Chaco and Santiago del Estero Provinces (Fig. 1). The study area covers the humid and semi-arid subregions of the Chaco, differentiated by an east-west rainfall gradient (Morello \& Adamoli, 1968). The humid Chaco, with a total annual rainfall of up to $1,200 \mathrm{~mm}$, is a mosaic of swamps, reedbeds and gallery forests; the dominant vegetation is semi-deciduous tall forest intermingled with grasslands (Bucher, 1982). There are three protected areas within our study area in this subregion: Pilcomayo (47,000 ha) and Chaco (15,000 ha) National Parks, and Pampa del Indio Reserve (8,600 ha). This subregion is well developed and has a high percentage cover of agriculture (Torrella et al., 2003). The semi-arid Chaco, with a total annual rainfall of up to $700 \mathrm{~mm}$ and a 6-7 month dry season (Bucher, 1982), is dominated by medium-tall dry forest. There are five protected areas in this subregion: Copo National Park (114,000 ha) and Copo (70,000 ha), Formosa (9,000 ha), Loro Hablador (23,750 ha) and Fuerte Esperanza (28,200 ha) Reserves. This subregion has a low human density and little agricultural development. Most inhabitants are peasants living in small settlements throughout the forest, with a subsistence lifestyle

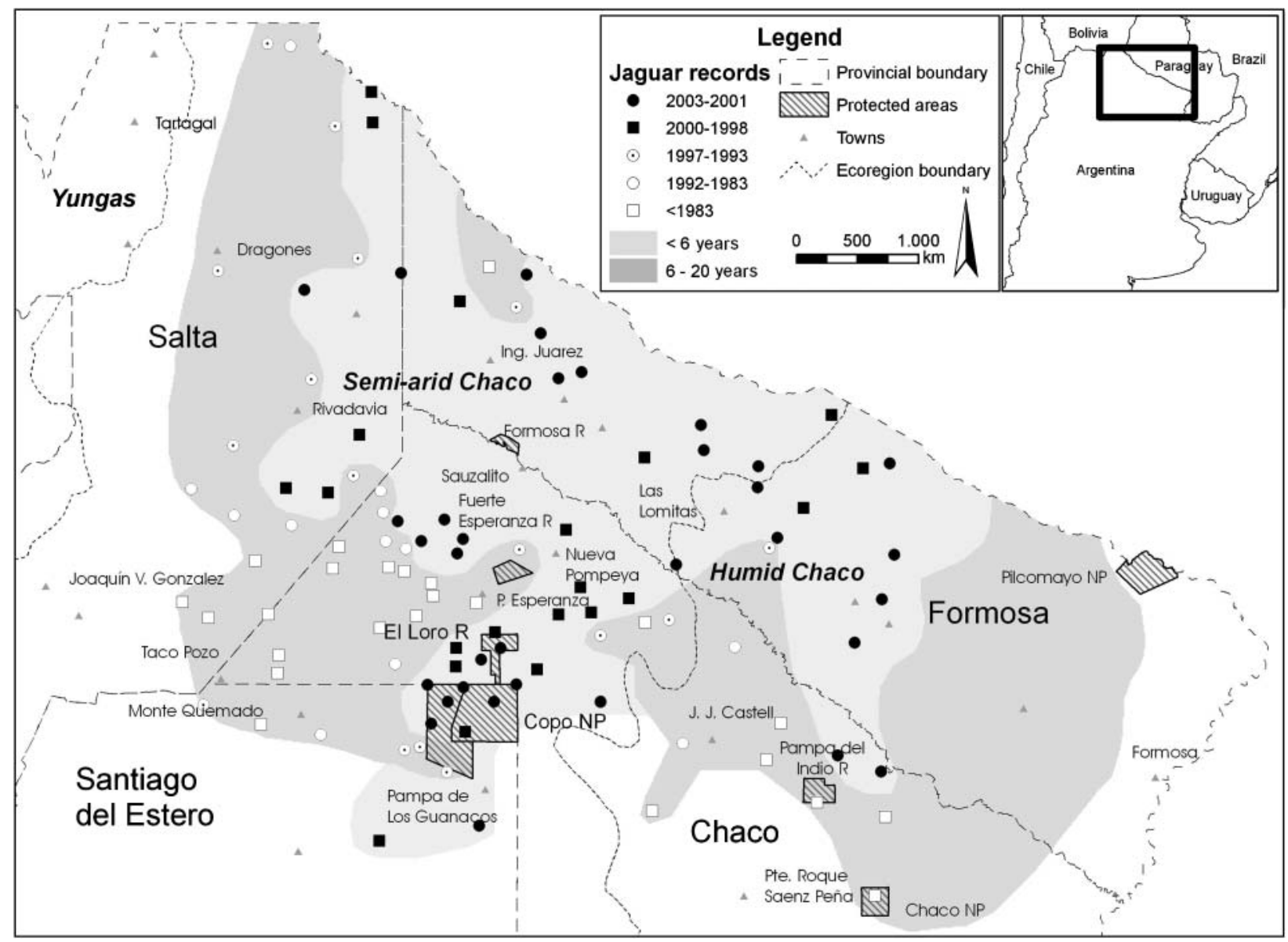

Fig. 1 Signs of jaguar presence since 1920 in the Argentine Chaco, with the location of National Parks (NP) and Reserves (R). The ecoregion boundary is between the semi-arid and humid Chaco (see text for details). The inset indicates the location of the main map on the Argentine - Paraguay border. 
based on livestock breeding and small-scale forest exploitation.

\section{Methods}

We carried out our surveys from 1997 to 2003, visiting different parts of the study area $>20$ times, each time for 30-90 days. We collected information on jaguar presence mainly through interviews with local people (400), other researchers (9), park rangers (11) and personnel of provincial wildlife agencies (3). We interviewed local people from rural areas, most of whom (95\%) were mestizo peasants. Interviews were conducted in Spanish (our native language). We used semi-structured interviews (Bernard, 1995) consisting of questions that addressed: (1) level of knowledge of the topic (time living in the area, time spent in the forest, hunting activities, identification of different felid species and their tracks), (2) information on sightings of jaguars and tracks, domestic animals killed by jaguars, jaguars hunted or captured alive, and the last year that jaguars were seen, and (3) location of last sign of jaguar presence, on a map. When there was more than one indication of jaguar presence for a single site and year we used only one. As part of other research we have spent time living with various rural families in the area (1997-2003), allowing us to develop a rapport with local people and increase our ability to assess the reliability of their reports. Information was considered reliable when there was consistency among different informants, and interviewees demonstrated ability to differentiate between tracks of jaguars and pumas Puma concolor. Local people are familiar with puma tracks because this species often repeatedly attacks their goats. Predation by pumas on cattle is rare and thus when locals find carcasses of cattle that have been attacked by a large predator they are confident that it has been a jaguar.

Twenty-eight percent of jaguar records were collected by ourselves. We confirmed $8 \%$ of other reports by observing animal parts (skulls, skins or feet) that people traditionally save and/or by photographs. Dubious data were not included, and scats were only included as data when observed by us or corroborated by several informants. The wildlife agencies of El Chaco and Formosa
Provinces provided information on confiscation of jaguar hides, jaguars captured alive and on killings of jaguars. We also collected information through our own observations of tracks, faeces, and livestock preyed upon by jaguars. When we had recent information on jaguar sightings or attacks on livestock we walked the forest in that area searching for tracks, carcasses and/or other signs. Where we had reliable information on jaguar presence we recorded locations using a global positioning system. Because of the varied sources and types of information we gathered, we refer to our data as signs of jaguar presence.

To ascertain whether local disappearance of jaguars was related to human colonization, we performed a correlation analysis using the age of settlements as the explanatory variable and the time of the last sign of jaguar presence as the response variable. For this analysis we only used information from sites in the semi-arid Chaco, covering c. $30,000 \mathrm{~km}^{2}$, where there has been little conversion of forest into agriculture land.

We addressed local people's perceptions of jaguars in western Chaco Province (Fig. 1) from 2001 to 2003 using ethnographic methods while frequently visiting and spending time with 38 local families as part of other research. We also obtained information on relative levels of livestock mortality and causes by interviewing local ranchers (30) and veterinarians (4) and through direct observation. We were not able to quantify livestock mortality because different factors often affect cattle simultaneously (e.g. starvation and diseases), and because most local people did not know the number of livestock they own.

\section{Results}

\section{Jaguar's range}

We collected 112 records of jaguar presence from approximately 1920 to 2003 (Table 1, Appendix 1). Signs of jaguar presence within the last 6 years were reported mainly in the semi-arid subregion (96\%). The two recent reports of jaguar presence in the humid subregion, north of Pampa del Indio Reserve (Fig. 1), were from two large

Table 1 Type of signs of jaguar presence in the five time periods considered.

\begin{tabular}{|c|c|c|c|c|c|}
\hline \multirow[b]{2}{*}{ Type of record } & \multicolumn{5}{|c|}{ Number $(\%)$ of records } \\
\hline & 1920-1982 & 1983-1992 & 1993-1997 & 1998-2000 & 2001-2003 \\
\hline Tracks \&/or faeces & $6(26)$ & $9(56)$ & $17(60)$ & $4(57)$ & $16(42)$ \\
\hline Sightings & $8(35)$ & $4(25)$ & $5(18)$ & $2(29)$ & $9(24)$ \\
\hline Jaguars killed \&/or trapped & $9(39)$ & $3(19)$ & $6(22)$ & $1(14)$ & $10(26)$ \\
\hline Took domestic prey & 0 & 0 & 0 & 0 & $3(8)$ \\
\hline Total & 23 & 16 & 28 & 7 & 38 \\
\hline
\end{tabular}


private ranches $(30,000$ and 10,000 ha) where there has been little deforestation and hunting is forbidden.

The frequency of signs of jaguars reported by locals and observed by us were highest in an area encompassing Copo National Park and Loro Hablador Reserve and in the central northern part of Formosa. Assuming that jaguars may still exist where signs of their presence have been reported within the last 6 years, we identified current jaguar distribution as an area encompassing central and western Formosa Province, western Chaco Province except for the south-west, north-eastern Santiago del Estero Province, and an area along the eastern boundary of Salta Province (Fig. 1). From this, using the geographic information system ArcView 3.3 (ESRI, Redlands, USA) we estimated that the total area of current jaguar distribution in the Chaco is c. $79,000 \mathrm{~km}^{2}$. Using the locations where jaguars were observed between 6 and 20 years ago, we estimated that jaguar range has been reduced by $90,000 \mathrm{~km}^{2}$.

The jaguars' range in the semi-arid Chaco appears to have been reduced by colonization. There was a positive relationship between age of settlements and years since last sighting (Fig 2). The average age for settlements where signs of jaguar presence were reported within the last 6 years was 15.1 years. Except in the area neighbouring Copo National Park, no sightings of jaguars have been reported within the last 10 years in settlements $>35$ years old.

\section{Livestock predation and perceptions of jaguars}

Local people mentioned that many cattle were lost to jaguar predation and many jaguars killed during the early years of settlement in the region (up to 70-80 years earlier). Currently, however, cases of predation by jaguars are rare. We recorded six reliable reports of jaguars preying on cattle during our fieldwork, of which only one was a case of repeated attacks. In contrast, most interviewees $(72 \%)$ reported predation of goats by pumas at least once per year, often losing many goats in each predation event. Although we were not able to quantify livestock mortality, we estimated that in the semi-arid Chaco $>80 \%$ of deaths reported during our study period were at least partially attributable to the style of livestock management, which is extensive husbandry with little veterinary health care and no breeding strategies. The most common causes of livestock mortality were starvation, thirst, disease and parasites. Three of the 38 families with whom we worked lost $>50 \%$ of their livestock in one season because of disease or starvation.

All interviewees mentioned that jaguars are dangerous and injurious, and expressed a desire to eliminate them, although $73 \%$ of rural interviewees had never seen jaguars or signs of their presence. Other than one reported case of a human attacked by a jaguar in 1995, most interviewees (96\%) had never heard of jaguar attacks on humans, although most expressed fear of jaguars. The persecution and killing of jaguars does not appear to follow predation but is a continuous process. Jaguars are persecuted as soon as their tracks have been observed in the forest. In contrast, pumas are generally persecuted only after they have attacked goats. Although the extermination of jaguars seems to be the main motivation for hunting this species, some people also sell jaguar hides to local traders. We learned of two recent cases where local people sold jaguar skins. However, we did not find evidence of local people making a living from selling jaguar hides as was apparently common, according to interviewees, in the past.

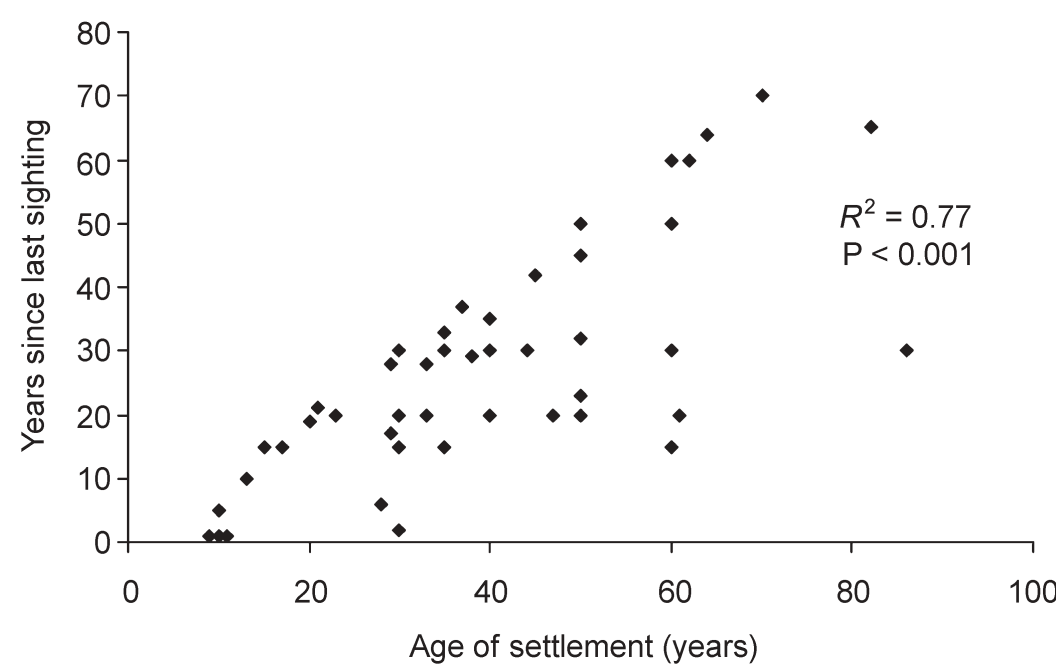

(C) $2006 \mathrm{FFI}$, Oryx, 40(3), 302-309
Fig. 2 Relationship between years since last sighting of jaguars and the age of settlement of an area. 


\section{Discussion}

Our findings suggest that jaguars in the Chaco are separated from those of the Paranaense forest of Misiones and of the Yungas, as indicated by Olrog \& Lucero (1981), and that the jaguars' range in the Chaco has been reduced substantially within the last 10 years. This population is isolated by agriculture and high human densities. Although Roig (1991) noted that, within the Chaco region, jaguars are more abundant in eastern Formosa and northern Salta, our findings suggest that they have disappeared from the former but still occur in central northern Formosa. This area has a low human density, a variety of environments and periodic inundations from the Pilcomayo River and wetlands that impede further development and agriculture. We also found that jaguars were observed more frequently in Copo National Park and surroundings areas than in the rest of the surveyed area. Using minimum estimates of 2-5 jaguars per $100 \mathrm{~km}^{2}$ for an unhunted site in the Bolivian Chaco (Maffei et al., 2004), we estimate that Copo National Park could harbor 23-60 jaguars.

Based on our observations of agricultural and urban development we believe that the jaguar population of the Chaco is probably isolated from the other two jaguar populations of Argentina: in the Yungas of Salta and Jujuy and in the forest of Misiones. To the east and west of the estimated current jaguar distribution in the Chaco region there is intensive logging, forest fragmentation and development of agriculture. However, the Argentine Chaco jaguar population is probably not isolated from the Paraguayan Chaco jaguar population. The region along the Pilcomayo River that separates Argentina and Paraguay is little developed and the presence of wetlands impedes human access.

There may have been several causes of the reduction in the jaguars' range in the Chaco. Hunting for the fur trade was an important mortality factor until Argentina joined CITES in 1980. Habitat loss has probably affected jaguar persistence in the humid and transitional subregions given the high rates of conversion of forest to agriculture (Torrella et al., 2003). High mortality of large carnivores as humans advance into wild areas is a worldwide phenomenon (Woodroffe \& Ginsberg, 2000). In the semi-arid Chaco, where colonization has not been associated with massive deforestation, we presume that hunting motivated by a desire to exterminate jaguars is the main threat. Although high human densities have the greatest effects on large mammals (Woodroffe, 2000; Parks \& Harcourt, 2002), in the semi-arid Chaco the existence of small settlements over more than 35 years has led to local extirpations of jaguars even when enough forest cover remains, as is the case for other large carnivores (Woodroffe \& Ginsberg, 2000). Jaguars can apparently survive in areas with slight disturbance if there is enough vegetation cover and prey (Aranda, 1996), but not if there is high hunting pressure (Swank \& Teer, 1989). It is difficult to evaluate hunting pressure in the semi-arid Chaco, but the low number of reports of jaguar signs around settlements that are 10 or more years old suggests hunting pressure is high. The proportion of animals killed (26\%) from the total number of reports of jaguars from 2001 to 2003 indicates there was high removal of individuals. This percentage is higher than the $18.4 \%$ over a period of 10 years in the Yungas (Perovic \& Herran, 1998).

The impact of hunting outside protected areas or at their boundaries can cause extinction of carnivores inside protected areas (Woodroffe \& Ginsberg, 2000; Harcourt et al., 2001). The effectiveness of the few protected areas in the Argentine Chaco in protecting jaguars is questionable. The two reserves that protect humid forest in El Chaco Province are small and isolated, and no sightings of jaguars have been reported in more than 15 years. Although home range and movements of jaguars in the Chaco are unknown, the $5,486 \mathrm{~km}^{2}$ estimated minimum area required for a viable jaguar population of 500 individuals (Redford \& Robinson, 1991) suggests that Copo National Park $\left(1,840 \mathrm{~km}^{2}\right)$ alone will not be enough to protect jaguar populations. The effective size of this Park is further reduced by the presence of people living inside, and hunting along the borders by people from nearby towns. The areas outside Copo are becoming more populated and forest exploitation is increasing (Caziani et al., 2003).

Jaguar-livestock conflicts in Latin America are common (Weber \& Rabinowitz, 1996; Polisar et al., 2003) and in the Chaco where the ranges of jaguars and livestock overlap completely we were surprised at the small number of reports of predation. This same type of cattle husbandry did, however, generate conflicts during the colonization of the semi-arid Chaco. As livestock management has not changed we presume that the low levels of predation are an indication of low jaguar abundance. Similar livestock management is currently generating high conflict with jaguar predation in the other two areas that support jaguar populations in Argentina (Perovic, 2002a; Schiaffino et al., 2002).

The negative attitude of people towards carnivores is a widespread phenomenon, reflecting a history of predation and competition (Kellert, 1996; Johnson et al., 2000; Conforti \& Azevedo, 2003). We found that fear of jaguars, rather than predation of livestock, was driving people to kill jaguars. This perception of jaguars exists throughout the jaguars' range, even though unprovoked attacks by jaguars on humans are rare (Sillero \& Laurenson, 2001; Conforti \& Azevedo, 2003; Crawshaw, 2004). Although attitudes can become more positive when knowledge of 
predators increases (Conforti \& Azevedo, 2003), or when people learn to appreciate them as a symbol of wilderness (Mech, 1970), this is unlikely to happen in the Chaco where the attitude to wilderness per se is negative. Mestizo peasants talk about the natural forest as dirty and agricultural fields as clean. Attitudes can also change when local people are involved with activities that bring benefits such as ecotourism from the conservation of jaguars (Miller, 2002; Conforti \& Azevedo, 2003). However, there are few examples where ecotourism or sport-hunting have resulted in carnivore conservation (Rabinowitz, 1995; Sillero \& Laurenson, 2001; Miller, 2002), and this is not a viable option for the Chaco given the poor infrastructure development, harsh climatic conditions, and the dense vegetation that impedes visibility of fauna.

In this situation the most important measure that could be contemplated is the creation of protected areas. Given the accelerated deforestation that is currently occurring in the Chaco (Zak et al., 2004) it is imperative to promote land use planning that incorporates a network of private, small state reserves, corridors, national parks and buffer areas. A potential corridor is the area between Copo National Park in the south and Paraguay in the north, passing through Loro Hablador, Fuerte Esperanza and Formosa Reserves. This proposed corridor, an area with low human population and abundant state land, could connect the Argentine Chaco population with those of the Paraguayan (Neris et al., 2002) and Bolivian Chaco (Maffei et al., 2004). Reports of regular sightings of jaguars between Copo National Park and Loro Hablador Reserve suggest that animals move between these areas. The recently annexed land to the south of the Loro Hablador Reserve is a first step in connecting these reserves. The remaining land between reserves should be managed under a protection regime that does not necessarily imply the exclusion of other uses, such as livestock ranching or selective logging, which could be compatible with jaguar conservation (Perovic, 2002b). Protection of large wide-ranging mammals cannot, however, stop at reserve borders (Woodroffe, 2001) and the existence of protected areas alone will not guarantee the persistence of jaguars if poaching continues.

Prospects for long-term persistence of jaguars in the Argentine Chaco are unfavourable, in contrast to the Bolivian Chaco where there is a large protected area and low human density (Maffei et al., 2004). Our study indicates that the jaguars' range and population have been reduced since the colonization of the Chaco, and current density is low. Jaguars have been almost completely extirpated from the humid Chaco, and remaining populations in the semi-arid Chaco are associated with areas of low human density, low levels of deforestation and protected areas. The situation in this region, however, changed rapidly during our study. Forest exploitation is increasing and the agricultural frontier is advancing even into marginal areas (Torrella et al., 2003; Zak et al., 2004). The area occupied by agriculture is predicted to increase fourfold in the next 6 years with the expansion of soybean plantations and pastures for intensive grazing (Torrella et al., 2003). Besides the creation of protected areas, we believe that solutions have to include reduction of human-produced mortality through enforcement of hunting regulations and increasing protection in existing reserves. Long-term solutions should include education in schools, geared towards fostering coexistence with jaguars. Hunting control and protected areas seem to be, at least in the short term, necessary measures to preserve a species such as the jaguar in a situation where fear is driving its extermination.

\section{Acknowledgments}

We thank the people of the Chaco, the National Park Service and the Wildlife Agencies for providing information. MA and GB conducted this study whilst doing research on wildlife use in a project coordinated by the Dirección de Fauna y Flora Silvestres of Argentina, funded by the governments of Italy and Switzerland. PP acknowledges funds received from CONICET and APNGEF-BIRF. We thank William Shaw, Robert Steidl, Peter, Ruth Sherman and the reviewers for their comments and suggestions.

\section{References}

Aranda, M. (1996) Distribución y abundancia del jaguar, Panthera onca (Carnivora: Felidae) en el estado de Chiapas, México. Acta Zoologica Mexicana, 68, 45-52.

Arra, M.A. (1974) Distribución de Leo onca (L) en Argentina. Neotropica, 20, 156-158.

Bernard, H.R. (1995) Research Methods in Anthropology: Qualitative and Quantitative Approaches. 2nd edition. AltaMira Press, London, UK.

Bucher, E.H. (1982) Chaco and Caatinga: South American arid savannas, woodlands and thickets. In Ecology of Tropical Savannas (eds B. Huntley \& B. Walker), pp. 48-79, Ecological Studies 42, Berlin, Springer-Verlag, Germany.

Bucher, E.H. \& Huszar, P.C. (1999) Sustainable management of the Gran Chaco of South America: ecological promise and economic constraints. Journal of Environmental Management, 57, 99-108.

Caziani, S.M., Trucco, C.E., Perovic, P.G., Tálamo, A., Derlindati, E., Adámoli, J., Lobo, F., Fabrezi, M., Srur, M., Quiroga, V. \& Martínez Oliver, M.I. (2003) Línea de Base y Programa de Monitoreo de Biodiversidad del Parque Nacional Copo. Proyecto de Conservación de la Biodiversidad-BIRF/GEF TF 028372 AR, Administración de Parques Nacionales, Buenos Aires, Argentina.

Conforti, V.A. \& Azevedo, F.C.C. (2003) Local perceptions of jaguars (Panthera onca) and pumas (Puma concolor) in the Iguacu National Park area, south Brazil. Biological Conservation, 111, 215-221. 
Crawshaw, P.G. (2004) Depredation of domestic animals by large cats in Brazil. Human Dimensions of Wildlife, 9, 329-330.

Guggisberg, C.A.W. (1975) Wild Cats of the World. Taplinger Publishing, New York, USA.

Harcourt, A.H., Parks, S.A. \& Woodroffe, R. (2001) Human density as an influence on species/area relationships: double jeopardy for small African reserves? Biodiversity and Conservation, 10, 1011-1026.

Hoogesteijn, R., Hoogesteijn, A. \& Mondolfi, E. (1993) Jaguar predation and conservation: cattle mortality caused by felines on three ranches in the Venezuelan llanos. Symposium of the Zoological Society of London, 65, 391-407.

IUCN (2006) 2006 IUCN Red List of Threatened Species. IUCN, Gland, Switzerland [http://www.redlist.org, accessed 18 May 2006]

Johnson, W.E., Eizirik, E. \& Lento, G.M. (2000) The control, exploitation and conservation of carnivores. In Behaviour and Conservation (eds M. Gosling \& W. Sutherland), pp. 197-219. Cambridge University Press, Cambridge, UK.

Jorgenson, J.P. \& Redford, K.H. (1993) Humans and big cats as predators in the Neotropics. Symposium of the Zoological Society of London, 65, 367-390.

Kellert, S.R. (1996) The Value of Life. Island Press, Washington DC, USA

Kellert, S.R., Black, M., Rush, C.R. \& Bath, A.J. (1996) Human culture and large carnivore conservation in North America. Conservation Biology, 10, 977-990.

Maffei, L., Cuéllar, E. \& Noss, A. (2004) One thousand jaguars (Panthera onca) in Bolivia's Chaco? Camera trapping in the Kaa-Iya national Park. Journal of Zoology, 262, 295-304.

Manfredo, M.J. \& Dayer, A.A. (2004) Concepts for exploring the social aspects of human-wildlife conflict in a global context. Human Dimensions of Wildife, 9, 317-328.

Mech, L.D. (1970) The Wolf: The Ecology and Behavior of an Endangered Species. The Natural History Press, Garden City, New York, USA.

Miller, C.M. (2002) Jaguares, ganado y humanos: un ejemplo de coexistencia pacífica en el noroeste de Belice. In El Jaguar en El Nuevo Milenio (eds R.A. Medellin, C. Equihua, C.L.B. Chetkiewicz, P.G. Crawshaw, A. Rabinowitz, K.H. Redford, J.G. Robinson, E.W. Sanderson \& A.B. Taber), pp. 477-491, Fondo de cultura económica, Universidad Nacional Autónoma de México, Wildlife Conservation Society, México.

Morello, J. \& Adamoli, J. (1968) Las Grandes Unidades de Vegetación y Ambiente del Chaco Argentino. Primera Parte: Objetivos y Metodología. Serie Fitogeografica, No. 10, Instituto Nacional de Tecnología Agropecuaria, Argentina.

Neris, N., Colmán, F., Ovelar, E., Sukigara, N. \& Ishii, N. (2002) Guía de Mamíferos Medianos y Grandes del Paraguay. Secretaría del Ambiente, Agencia de cooperación internacional del Japón, Asunción, Paraguay.

Novell, K. \& Jackson, P. (1996) Wild Cats: Status Survey and Conservation Action Plan. IUCN/SSC Cat Specialist Group, Gland, Switzerland.

Olrog, C.C. \& Lucero, M. (1981) Guía de los Mamíferos Argentinos. Ministerio de Cultura y Educación y Fundación Miguel Lillo, San Miguel de Tucumán, Argentina.

Parks, S.A. \& Harcourt, A.H. (2002) Reserve size, local human density, and mammalian extinctions in US protected areas. Conservation Biology, 16, 800-808.

Perovic, P. (2002a) Conservación del jaguar en el noroeste de Argentina. In El Jaguar en El Nuevo Milenio (eds R.A. Medellin, C. Equihua, C.L.B. Chetkiewicz, P.G. Crawshaw,
A. Rabinowitz, K.H. Redford, J.G. Robinson, E.W. Sanderson \& A.B. Taber), pp. 465-475, Fondo de cultura económica, Universidad Nacional Autónoma de México, Wildlife Conservation Society, México.

Perovic, P. (2002b) Ecología de la Comunidad de Félidos en las Selvas Nubladas del Noroeste Argentino. PhD thesis, Universidad Nacional de Córdoba, Córdoba, Argentina.

Perovic, P.G. \& Herran, M. (1998) Distribución del jaguar panthera onca en las provincias de Jujuy y Salta, Noroeste de Argentina. Mastozoología Neotropical, 5, 47-52.

Polisar, J., Maxit, I., Scognamillo, D., Farrell, L., Sunquist, M.E. \& Einsberg, J.F. (2003) Jaguars, pumas, their prey base, and cattle ranching: ecological interpretations of a management problem. Biological Conservation, 109, 297-310.

Rabinowitz, A. (1995) Jaguar conflict and conservation: a strategy for the future. In Integrating People and Wildlife for a Sustainable Future (eds J.A. Bissonete \& P.R. Krausman), pp. 394-397. The Wildlife Society, Bethesda, USA.

Redford, K.H. \& Eisenberg, J.F. (1992) Mammals of the Neotropics, Vol 2: The Southern Cone. University of Chicago Press, Chicago, USA.

Redford, K.H. \& Robinson, J.G. (1991) Park size and the conservation of forest mammals in Latin America. In Latin American Mammalogy: History, Biodiversity and Conservation (eds M.A. Mares \& D.J. Schmidly), pp. 227-234. University of Oklahoma Press, Norman, USA.

Roig, V.G. (1991) Desertification and distribution of mammals in the southern cone of South America. In Latin American Mammalogy: History, Biodiversity and Conservation (eds M.A. Mares \& D.J. Schmidly), pp. 239-279. University of Oklahoma Press, Norman, USA.

Sanderson, E.W., Redford, K.H., Chetkiewicz, C.L.B., Medellin, R.A., Rabinowitz, A., Robinson, J.G. \& Taber, A.B. (2002) Planning to save a species: the jaguar as a model. Conservation Biology, 16, 58-72.

Schiaffino, K., Malmierca, L. \& Perovic, P.G. (2002) Depredación de cerdos domésticos por jaguar en un área rural vecina a un parque nacional en el noreste de Argentina. In El Jaguar en El Nuevo Milenio (eds R.A. Medellin, C. Equihua, C.L.B. Chetkiewicz, P.G.. Crawshaw, A. Rabinowitz, K.H. Redford, J.G. Robinson, E.W. Sanderson \& A.B. Taber), pp. 251-264, Fondo de cultura económica, Universidad Nacional Autónoma de México, Wildlife Conservation Society, México.

Sillero, Z.C. \& Laurenson, M.K. (2001) Interactions between carnivores and local communities: conflict or co-existence? In Carnivore Conservation (eds J.L. Gittleman, S.M. Funk D.W. MacDonald \& R.K. Wayne), pp. 282-312. Cambridge University Press, Cambridge, UK.

Swank, W.G. \& Teer, J.G. (1989) Status of the jaguar. Oryx, 23, 14-21.

Torrella, S., Herrera, P. \& Adamoli, J. (2003) Sostenibilidad de la Expansión Agraria en la Región Chaqueña: Condiciones Favorables y Factores Limitantes. 3as Jornadas Interdisciplinarias de Estudios Agrarios y Agroindustriales, ISBAN, Buenos Aires, Argentina.

Weber, W. \& Rabinowitz, A. (1996) A global perspective on large carnivore conservation. Conservation Biology, 10, 1046-1054.

Woodroffe, R. (2000) Predators and people: using human densities to interpret declines of large carnivores. Animal Conservation, 3, 165-173.

Woodroffe, R. (2001) Strategies for carnivore conservation: lessons from contemporary extinctions. In Carnivore Conservation (eds J.L. Gittleman, S.M. Funk, D.W. Macdonald 
\& R.K. Wayne), pp. 61-92. Cambridge University Press, Cambridge, UK.

Woodroffe, R. \& Ginsberg, J. (2000) Ranging behaviour and vulnerability to extinction in carnivores. In Behaviour and Conservation (eds M. Gosling \& W. Sutherland), pp. 125-140. Cambridge University Press, Cambridge, UK.

Zak, M.R., Cabido, M. \& Hodgson, J.G. (2004) Do subtropical seasonal forests in the Gran Chaco, Argentina, have a future? Biological Conservation, 120, 589-598.

Zimmerman, A., Walpole, M.J. \& Leader-Williams, N. (2005) Cattle ranchers' attitudes to conflicts with jaguar Panthera onca in the Pantanal of Brazil. Oryx, 39, 406-412.

\section{Appendix}

This paper contains supplementary material that can only be found online at http://journals.cambridge.org

\section{Biographical sketches}

Mariana Altrichter has studied the ecology of white-lipped peccaries in a Costa Rican lowland rainforest, the uses of wildlife by peasants and indigenous people in Costa Rica, and the relationship between the nomadic movements of peccaries and their illegal hunting. Since 1997 she has focused on the study of wildlife-human conflicts from an interdisciplinary perspective, addressing the human and ecological dimensions of conservation of endangered species as a way to achieve more realistic and efficient solutions.

Gabriel Boaglio's principal interest is in wildlife conservation. He is currently working on a project for the sustainable harvest of Amazona aestiva by local peasants in the Argentine Chaco with the Fauna and Flora National Agency.

Pablo Perovic has studied the ecology of many different species of felids in the north-west of Argentina since 1992. He has also studied livestock-jaguar conflicts in the same region. 